\title{
The Historical Basis Of The Plot Of The Epics Of Yusuf And Zulaykho
}

\author{
Nazokat Babadjanova \\ Teacher of the Faculty of Pedagogy, Urgench State University, Uzbekistan.
}

Article History:Received:11 January 2021; Accepted: 27 February 2021; Published online: 5 April 2021

\begin{abstract}
The article analyzes the history of the emergence and development of works of art based on the plot of "Yusuf and Zulayho." Different opinions have been expressed about the historical roots of the story of Joseph and the ancient sources that formed the basis of the series of images. Certain attempts to identify the primary sources on which the planetary plot originated have been observed. The expression of the plot in religious sources and creative interpretations in the written literature are analyzed.
\end{abstract}

Keywords: Written literature, epic plot, religious book, classical literature, motive, myth, image, narration, folklore, folklore, mythology, religious story, version, variant, mythopoetic interpretation, character, genetic basis, motive.

\section{Introduction}

Is known that in written literature there is a long history of the emergence and development of works of art based on the plot of the story of Joseph. In world literature, there are different opinions about the historical roots of the story of Joseph and the ancient sources that formed the basis of this image. It should be noted that the issue of identifying the primary source on which the story of Yusuf (as) is based has not been universally accepted in the literature. A.M. Akhunov, who studied the sources of medieval Tatar classical literature in Arabic, wrote, "The disputes between the representatives of different religious denominations over the nationality and religion of Yusuf (as) have not stopped. Is Joseph a Muslim, a Jew, or a Christian? That is the main issue that is causing controversy. At this point, the question arises as to what extent certain elements of this plot are assimilated from different cultures, and whether the subject in general is the subject of assimilation itself. There are different views on this subject in the scientific literature: researchers of agiographic sources of Christianity believe that Islam has adopted this plot from the Bible; atheists consider the story of Joseph in the Qur'an to be an interpretation of the story of Joseph in the Bible; According to Islamic scholars, the Psalms, the Bible and the Qur'an are sacred books revealed by Allah. This is the reason for the similarity and similarity in the interpretations of the story of Yusuf (as) in these books. "[1. -P. 19-20]

Nevertheless, there have been certain attempts in world literature to identify the primary sources that gave rise to the plot of this extremely beautiful story. For example, when O.M. Freidenberg, a well-known literary scholar who studied the ancient literature of the peoples of the world in connection with mythology, spoke about the essence of this plot, the myth of Joseph of Gulyuzli, I did not mean the history of the hero of the Bible. I understand the mythological fable that an innocent man is sentenced to death for slandering an unattainable woman, but by the will of fate the young man escapes unjust punishment, and the slanderous wife is executed. The plot bears no resemblance to the ancient Egyptian myth of the Two Brothers, the legend of the Seven Wise Men, popular among the ancestors of the Indians, and the myth of the "Syrian goddess" recorded among the indigenous peoples of Asia Minor thousands of years ago. He speculates that the origin of the Gospel account of Josephus is rooted in ancient Egyptian myths about Osiris and Adonis. [2. -P. 137-138]

Well-known Turkmen literary critic M. Soegov traces the first source of the Judeo-Christian-Islamic story about Yusuf from ancient Indian Buddhist sources on the basis of the analysis of the Russian translation by S.E. [3. -P. 14] In this legend, the younger of the two brothers, the younger brother, agrees to be a hungry tiger, and the suffering of his father, who is aware of this, sounds like how much Jacob cried when he heard the news that Joseph was a wolf. , in fact, the Uyghur legend appears to have originated on the basis of a planetary plot.

According to SK Azerbaev, a Tajik scholar who has studied the history and sources of the story of Yusuf, the origin of the image of the protagonist of the story of Yusuf in the Bible and the Koran is the Egyptian sage Imkhotep (XVII-XVI centuries BC). the ancient form of the name of the person is associated with legends about Imutes). Because according to the information received through the ancient Egyptian papyri, the sevenyear drought occurred during the time of Imhotep. Moreover, the ethnic origins of the Egyptian pharaohs who ruled in the seventeenth and sixteenth centuries BC belonged to the ancient Jewish peoples who spoke Semitic languages. The scholar writes, "According to a papyrus inscription found on the island of Sahel, the news of the coming seven-year drought will be revealed to Pharaoh Joser in a dream. He advises every city to gather enough grain. Thus, the oral stories about Imhotep developed over time and became legends, and the name of the great sage began to be referred to in the legends by Futifar, Potifor, Ibn Riyan, and others. The historical basis of the story of the image of Joseph goes back to real life events that took place in the lives of Semitic- 
speaking peoples living in ancient Egypt. In the ancient book of the Jews, this story was interpreted in a religious spirit. " [4. -P. 76-84]

According to H.O. Safarova, who studied the chapter "The Story of Yusuf" by "Qisasi Rabguzi", "The romantic adventure of Yusuf and Zulayho is very ancient and originated in the oral tradition of Arabs and Jews. It was then passed on to the holy religious books, including the Torah and the Psalms, which were first considered the Old Testament, and then the Gospel, which was considered the New Testament. Finally, it is expressed in the Qur'an in the form of a separate surah. " [5. -P. 17]

\section{Materials and methods}

It is well known that Joseph's patience, devotion, and honesty are glorified in the expression of the story of Prophet Joseph in religious sources and in the creative interpretations of written literature by describing the strange adventures of a son who was thrown into a well as a result of his brothers' carelessness and blindness. Consequently, the fact that the knot in the composition of the story composition is directly related to the relationship of the brothers allows us to connect the source of the origin of this plot to the ancient Egyptian folklore.

In the middle of the 19th century, the French archaeologist d'Orbini discovered a hieroglyphic inscription on twelve papyri written by a scribe named Ennana in the 13th century BC. Experts have determined that this parirus was written during the reign of Seti II, who ruled from $1200 \mathrm{BC}$ to $1194 \mathrm{BC}$, during the reign of Hakan, a member of the 19th dynasty of the new rulers of Egypt. It contains a myth, conditionally called "The Tale of the Two Brothers" by scholars, which is significant in that it belongs to the archaic folklore of the ancient Egyptians and was created long before Homer's famous Odyssey. It reads: "The old man and the old woman once had two sons, the eldest of whom was named Anubis and the youngest Bata. Anubis was married and had plenty of water and property, while Bata was doing housework like his son. Bata's brother, Anubis, did whatever he was told to do, tending his cattle, plowing the land, and reaping the harvest. Anubis treated him as kindly as his father. One day Anubis ordered Bata to prepare the oxen to plow the land and plant grain. Once the land was plowed and the grain was planted, the seed that had been brought in ran out of wheat, so Anubis sent it home to Bata to bring grain. Anubis's wife, who saw Bata carrying five sacks of wheat in one go, was amazed at the young man's strength. He stopped her at the gate and offered to be with her. If Bata accepted the offer, he promised to sew her a good dress. Outraged, Bata became very angry, flatly refused his new offer, and returned to the field, promising not to tell his brother what had happened. But Anubis's wife didn't believe it, painted her legs and pretended to be strangled, and when her husband came, Bata slandered her, saying that she had beaten him in an attempt to rape him. In a fit of rage, Anubis tried to kill his brother, but the innocent Bata prayed to the god $\mathrm{Ra}$ to save him. Ra took him under his protection and created a raging river in which crocodiles were swimming among the brothers. Bata, who had escaped from his brother, made the wooded valley his home, and the gods married him to a girl who was more beautiful than any other woman in the world. Fearing that his brother might come here too, Bata hid his heart in a tree called "ash".

One day, while Bata's wife was walking along the river bank, a strand of her golden hair fell on a tree branch and fell into the water and fell into the hands of Pharaoh. Pharaoh searched for the girl who had this golden hair, and somehow managed to win her heart and give her various gifts to marry. The melted woman wanted to be Pharaoh's maid, and her husband showed her the tree where Bata's heart was hidden. Bata died when Pharaoh's men cut down the tree that the girl pointed to. But the gods resurrected him again in the form of a baby. Pharaoh treated him as his own son, and after some time he was punished for the betrayal of his husband and the woman who caused his death. [6. -P. 77-78]

The motifs of this myth are that Anubis fell in love with Bata, the wife of Anubis, and slandered the young man when his love was rejected, Anubis tried to kill his brother, God created a river between the brothers, Bata disappeared to a land far from his brother, and Pharaoh's enmity. that the sons of the prophet Jacob in the construction of Joseph wanted to kill Joseph, that Joseph was thrown into a well (related to the concept of a river through the details of water), that Joseph was sold into Egypt as a slave (away from his brothers), that Zulaikha fell in love with Joseph's own slave It sounds like motives like slandering Joseph. This shows that the historical roots of the plot of the story of Joseph, which is the basis for the creation of unique artistic values as a result of the transformation of written literature through religious sources, go back to ancient Egyptian mythology of XIII-XII centuries BC.The plot of ancient Egyptian mythology, dedicated to the adventures of Anubis and Bata, later spread as a result of cultural ties, first to Ancient and Middle Asia, and then to other parts of Central Asia and Europe. A Kazakh fairy tale published by G.N. Potanin tells the story of a young man who is forced to flee to Id because his wife has slandered him. At the order of the halt, the minister followed in the footsteps of Janbay Idagi. When he reaches the river Adil, Janbay chases Idagi. Then Idiga miraculously crosses to the other side of the river, and Janbay does not cross (G.N. When he crossed the Idiga, he must have been described as having appeared behind him. This is reminiscent of the motive of his brother not being able to cross the river Bata in the myth of the Two Brothers. As in Egyptian mythology, in the Kazakh fairy tale Idi lives happily by the river, while Bata is married to the gods, and Idagi's friends bring Sattemir's daughter. [7. -P. 33] 
Apparently, the "mobile plot" was the basis for the formation of the Kazakh folk tale "Idiga". Tajik literary critic SK Azerbaev found that the ancient Egyptian fairy tale "The Tale of Straight and Curved", which is considered to belong to the XVII-XVI centuries BC, is very similar in content to the religious story of Joseph. In his view, this tale, which arose as a result of a mythopoetic interpretation of real historical events that took place in ancient Egypt, may have played a role in shaping the plot on the subject of Joseph. Another interesting fact, according to SK Azerbaev, is that "the legend of Yusuf (Joseph) was passed from language to language through a live oral tradition in the VI century BC and entered the folklore of the Persian-speaking population. This is because the fact that the Persian folk lyric epic Zirya and Avda, written in the same century, is close to the epic Yusuf and Zulaykha in terms of its theme and content gives grounds to assume that. "[8. -P. 6-7]

All these comparative materials show that the mythopoetic context, which was the primary source for the story of Joseph, was created in ancient Egypt, spread among the peoples of the region in the system of literary and cultural relations, and later became the "traveling plot" on which many commonly motivated folklore works.

If we analyze the plot of "The Story of Two Brothers" in terms of compositional structure, we see that it contains mythological motifs that are common in the world, including Uzbek folklore. For example, Anubis's slander of Bata, the wife of Anubis, who did not achieve her sexual desire, is in line with the slander of Joseph's wife, Panthepria, in the Bible. This motif is also found in the Uzbek folk novels "Erali and Sherali", "Sweet and Sugar". The chase of Anubis with the intention of killing his brother Bata may be one of the ancient types of motive for the persecution of the epic hero. Bata, who feared that his brother would ever find him, hid his heart inside a tree trunk under the influence of animistic myths about the existence of the soul outside the body. The most vivid example of this belief in Uzbek folklore is the fact that the souls of giants are like pigeons in a box, worms among stones, and in the fairy tale "Sword" the soul of the younger brother is in the sword. One of the elements of the plot, which is also typical of Uzbek folk tales, is the story of a golden-haired couple's hard work as a result of a strand of hair flowing in the river. The rebirth of Bata in the form of a baby with the help of the gods is a motif associated with ancient myths about the gods who die and rise again. In this regard, O.M. Freudenberg's connection with the genesis of the image of Joseph with Osiris in ancient Egyptian mythology [9. -P. 138] justifies itself.In this regard, let us comment on the scientific hypothesis of the well-known literary scholar HG Korogli that "the biography of Joseph in this plot is associated with the image of Siyavush in the Avesto" [10. -P. 336 ]. It is also clear from the above analysis that there is no direct connection between the origin of the image of Joseph and the image of Siyavush in the Avesto. There is one thing that connects these two images, and that is that the genetic basis of the image of Joseph (Joseph) depends on the mythical character Osiris, who embodied the cult of the dying nature in ancient Egyptian mythology. Because the image of Siyavush was also considered in the mythology of the ancient ancestors of the peoples of Central Asia as a symbol of the cult of the dying nature. [11. -P. 33-44]

Just as the heart (i.e., the soul) of Bata is hidden inside the trunk of a tree called ash, ancient Egyptian myths state that a sacred tree grows over the tomb of Osiris to guard it. [12. -P. 33] Both characters are associated with the tree and the cult of the resurrected nature. their connection shows that they are interdependent, that is, the image of Bata in The Tale of the Two Brothers is a mythopoetic transformation of Osiris, envisioned as a symbol of the cult of the dying nature. The English ethnographer J. Fraser also noted that in ancient myths, Osiris was thought of as the spirit of cereals, trees and plants. [13. -P. 169-197] It goes back to the myths about Osiris.

\section{Result and discussion}

Thus, the content of the myth of the "Two Brothers", which is considered to be the oldest form of the plot of "Joseph and Zulayha", became a "traveling plot" and moved to the holy religious books in various variants. In particular, it passed first to the Torah and the Psalms, which are the Old Testament, and then to the Bible, which is the New Testament. Later, the plot was further perfected and transferred to our holy religious book, the Holy Qur'an. In trying to shed light on the historical foundations of the plot of the epic, we try to analyze the ancient sources in which this theme is reflected. Indeed, "The plot of Yusuf's works of art is one of the rarest examples of transnational myths in world literature. Therefore, the expression of this plot in the context of world literature in the form of this or that work should be interpreted not as part of a particular religious system, but as an artistic interpretation of an ancient cultural archetype. "[14]

Formed and recorded in the thirteenth and twelfth centuries BC, the myth of the brothers has in fact been popular among the people for some time through live oral performances. Later, as he sealed the events of the Seti II dynasty on papyrus, Secretary Ennana also seems to have narrated the content of this myth, which he heard himself. Influenced by the oral traditions of this myth, the first examples of the epic plot about Joseph (Joseph) were first found in the Old Testament and the New Testament as religious narrations. The scriptures known as the Old Testament are called the Torah and the Psalms, and the New Testament is called the Bible. The Torah and the Psalms of Judaism were written in ancient Hebrew, while the Bible, which is recognized as 
the holy book of Christianity, was written in ancient Greek. It is in these sources that the interpretation of the story of Joseph in the form of a religious legend was first reflected.

The story of Joseph of Gulyuz was first narrated in the first book of the Torah, Genesis. This narration was later perfected and transferred to the Holy Qur'an, the holy book of Islam. The story of Yusuf is given in Surah 12 of the Qur'an, Surah Yusuf. [15. -P. 235-248] Alouddin Mansur, the translator of the Qur'an into Uzbek, commented on the reasons for the revelation of this Surah, which consists of one hundred and eleven verses about Yusuf. He writes: This surah was revealed after Surat al-Hud in the darkest days of Muhammad's life, when he was separated from his relatives Khadijah and Abu Talib and was being persecuted by the polytheists. It is as if Allah, glory unto Him, and His beloved Prophet and all his ummah, if they persevered in the calamities that befell them and the oppression of the unbelievers, and persevered in their struggle for the truth, and remained steadfast in the religion of Allah, [16. -P.157. Accordingly, the inclusion of this story about Yusuf in the Qur'an encourages people to be patient, to behave even in the most difficult days of life, and to overcome adversity with perseverance. is exemplary in its focus on encouraging necessity.

This surah is "Alif. Lom. Ra. These (verses) are clear verses of the Book. "On this revelation, MB Piotrovsky writes:" One hadith states that the third verse of Surah Yusuf: When one day the Companions asked Muhammad to tell an interesting story: "(O Muhammad), We narrate to you the best of narratives by revealing this Qur'an (Surah). But before that, you were of those who did not know. Then the most beautiful of the stories, the story of Yusuf, will be narrated. "[17. -P. 90]

According to the Qur'an, Yusuf dreamed that eleven stars, the sun and the moon worshiped him. When the father interprets his son's dream, he prophesies: "The Lord will choose you to prophesy and give you the ability to interpret people's dreams correctly." The special treatment of Jacob by Joseph and his younger brother Benjamin has a profound effect on the remaining ten brothers, and they try to put an end to it no matter what. The thought of killing Joseph or taking him to a distant land arises. Then one of them said, "Let's not kill Joseph, let's throw him into a well, and let one of the caravans take him away." This idea appeals to all of the brothers. They throw Joseph into a well. When he came home, he cried to his father, "Joseph was a wolf," and they showed him his bloody shirt. A caravan passing by the well rescues Joseph and takes him to Egypt. Joseph goes through many controversial events in Egypt. Alqissa finds out from her brothers and father. He lends a helping hand to them during the years of famine.

From the above brief analysis, it can be seen that the similarity in the interpretation of Yusuf's story in the Torah and the Qur'an is evident in the fact that Yusuf was thrown into a well by his ignorant brothers and deprived of the love of his parents. He is also imprisoned, at the instigation of the wife of the Egyptian lord. He will save the people of Egypt from starvation, and will forgive the cruelty of his brothers. The eyes of Prophet Ya'qub (as), who was blinded by his son's weeping in Hajj, were opened as soon as he rubbed Yusuf's shirt over his eyes. While Joseph is in prison, he interprets the dream of the king's butler and baker. The common interpretation of the king's dream and his release from prison show a commonality in both divine books. At the same time, in many respects, the verses in Surah Yusuf narrate the story of Yusuf (as) in many respects, such as the richness of the tablets in the Torah and the Bible, the beauty of the language, the environment in which the Arabs lived and the details of nature. it acquires originality by glorifying high spiritual and moral qualities. embodying the perfection of its content, the depth of its enlightenment and spiritual essence, and noble ideas, the plot of this story served as the main source for the creation of a number of works of art dedicated to the adventures of Yusuf and Zulayha in folklore and written literature of the Orient.

The plot of Yusuf's story is widely used in Arabic, Persian, Tajik, and Turkic folklore and written literature, mainly in the verses of Sura 12 of the Qur'an, its commentaries, and various interpretations of the stories of the prophets, including Nosiruddin Burhanuddin Rabguzi's Qissasul Anbiyo. served. Abu Ja'far Muhammad ibn Jarir ibn Yazid ibn Kathir ibn Talib at-Tabari (839-923) wrote a book on the origin of the romantic novels about Yusuf and Zulayha, "History of the Prophets and Kings." The chapters devoted to the interpretation of Yusuf's story in (this work was translated from Arabic into Persian-Tajik during the Samanid period) also played an important role. In particular, it is known that Tabari's "History" was the basis for the creation of the epic "Qissai Yusuf" by Kul Ali, a great representative of medieval Turkish literature.

\section{Conclusion}

In our opinion, one of the most important sources for the spread of Yusuf among the Uzbek people is a work by the famous linguist AK Borovkov, which dates back to the XII-XIII centuries and is called "Central Asian commentary" [18] Although the author of this commentary found in Karshi is unknown, but the fact that in his lexicon there is a clear lexical layer of the language of that period, indicates that this work was created in our country. This commentary, which interprets all the surahs of the Qur'an, including Surah Yusuf, in its own way, has been widely known for centuries in madrassas and schools, as well as among the educated population. This is the reason why the beautiful story of Yusuf (as) spread among the people and was popularized in the form of narrations, fairy tales and short stories through oral performances. 


\section{References}

1. Axunov A.M. Arab istochnik srednevekovoy tyurko-tatarskoy literatury: na materiale trudov atTabari. - Kazan: Izd-vo TGGI, 2001.

2. Freydenberg O.M. Myth of Iosife Prekrasnom // Yazyk i literatura. - T.8. - M., 1932.

3. Soegov M. Iudeysko-hristiansko-islamskiy syujet ob Iosife i buddiyskaya legenda o printse i golodnoy tigritse (po materialam ix perevodov, yazyka i iskusstva) // Jazyk a kultúra. - Prague, 2013. - 15íslo 15 (wwwff.unipo.sk >jak/15_2013/soegov.pdf).

4. Azorboev S.K. Ob istorii vozniknoveniya povesti o Yusufe // Vestnik tadjikskogo natsionalnogo universiteta. Series philology. №2. - Dushanbe: Sino, 2004.

5. Safarova H. Sources of Rabguzi's Qissai Yusuf Siddiq alayhis-salam: Philol. science nomz. diss. Samarkand, 2001.

6. A Tale of Two Brothers // Badj E.U. Egyptian tales, stories and legends. - M., 2009.

7. The content of this tale is taken from the following source: Vikentev V.M. Ancient-Egyptian story about two brothers. - M., 1917.

8. Azorabekov S.K. The story of Yusufe and ego reflection in Persian-Tajik prose X-XI centuries: Author. diss. kand. filol. science. - Dushanbe, 2005.

9. Freydenberg O.M Myth of Iosife Prekrasnom // Yazyk i literatura. - T.8. - M., 1932.

10. Korogly X.G Vzaimosvyazi eposa narodov Sredney Azii, Irana i Azarbeydjana. - M .: Nauka, 1983.

11. Dyakonov M.M. Obraz Siyavusha v sredneaziatskoy mifologii // Kratkie soobshcheniya instituta istorii materialnoy kultury. T.40. - M., 1951.

12. Vikentev V.M. Ancient-Egyptian story about two brothers. - M., 1917. - P.33 (this book was taken from the internet. See: www. Bookfi.net >book / 768732).

13. Fraser J. Zolotaya vetv. - M .: Politizdat, 1989.

14. Sharyafetdinov R.X. Transformation of the koranicheskogo plot of Iosife Prekrasnom in the poem Kul Gali "Kyssa-i Yusuf”: Author. diss. kand. filol. science. - M., 2009.

15. The Holy Quran. Uzbek annotated translation. - Tashkent: Tashkent Islamic University, 2001.

16. The Holy Quran. Uzbek annotated translation. - Tashkent: "Cholpon” publishing house, 1992.

17. Piotrovskiy M.B. Koranicheskie skazaniya. - M., "Nauka", 1991.

18. Borovkov A.K. Vocabulary of medieval interpretation XII-XIII vv. - M .: Nauka. 